\title{
Effects of feed quantitative restriction and coenzyme Q10 level on performance, plasma lipoproteins and organ weights of broiler chicks
}

\author{
H. Jahanpour ${ }^{1}$, M. Chamani ${ }^{1, *}$, A.R. Seidavi ${ }^{2}$, A.A. Sadeghi ${ }^{1}$ and M. Amin-Afshar ${ }^{1}$ \\ ${ }^{1}$ Department of Animal Science, Science and Research Branch, Islamic Azad University, \\ Tehran - Iran \\ ${ }^{2}$ Department of Animal Science, Rasht Branch, Islamic Azad University, Rasht - Iran \\ *CorrespondingE-mail: m.chamani@srbiau.ac.ir
}

Received. June 03, 2018; Accepted August 18, 2018

\begin{abstract}
ABSTRAK
Suatu percobaan dilakukan untuk menganisis efek tingkat pembatasan pakan dan durasi, dan tingkat koenzim Q10 diet pada kinerja pertumbuhan, karakteristik organ dan lipoprotein plasma. Desain faktorial yang didasarkan pada Rancangan acak lengkap dilakukan menggunakan dua tingkat pembatasan pakan (10 dan 20\% lebih sedikit daripada standar pedoman strain Ross 308), dua tingkat lama pembatasan (7 dan 14 hari) dan tiga tingkat koenzim Q10 ( 0, 20 dan $40 \mathrm{mg} / \mathrm{kg}$ pakan). Hasil penelitian menunjukkan bahwa intensitas pembatasan memiliki pengaruh yang nyata terhadap asupan pakan pada minggu pertama, kedua dan keenam $(\mathrm{P}<0,05)$, pertambahan berat badan pada minggu kedua dan keenam $(\mathrm{P}<0,05)$, dan rasio konversi pakan di minggu pertama usia $(\mathrm{P}<0,05)$. Durasi pembatasan berpengaruh nyata terhadap asupan pakan pada minggu ketiga usia $(\mathrm{P}<0,05)$, dan rasio konversi pakan pada minggu ketiga dan keenam $(\mathrm{P}<0,05)$. Tingkat koenzim $\mathrm{Q}$ memiliki pengaruh yang nyata terhadap asupan pakan pada minggu pertama dan keenam $(\mathrm{P}<0,05)$, pertambahan berat badan pada minggu kedua, kelima dan keenam $(\mathrm{P}<0,05)$, dan rasio konversi pakan pada minggu kedua dan keenam dari usia $(\mathrm{P}<0,05)$. Kesimpulan penelitian adalah efek positif dari pembatasan pakan dan koenzim Q10 pada hasil ayam pedaging, penggunaan strategi pembatasan pakan dan diet koenzim Q10 dapat digunakan sebagai program manajemen untuk meningkatkan produktivitas broiler.
\end{abstract}

Kata kunci : asupan pakan, pertumbuhan, rasio konversi pakan, HDL, ginjal

\begin{abstract}
An experiment was conduct in order to investigate the effects of feed restriction level and duration and dietary coenzyme Q10 level on growth performance, organ characteristics and plasma lipoproteins. A factorial arangment based on a completely randomized design was performed using two levels of feed restriction (10 and 20\% less than the standard Ross strain 308 guidelines), two levels of restriction duration (7 and 14 days) and three levels of coenzyme Q10 (0,20 and $40 \mathrm{mg} / \mathrm{kg}$ feed). The results of the experiment showed that restriction intensity had significant effect on feed intake in first, second and sixth weeks of age $(\mathrm{P}<0.05)$, body weight gain in second and sixth weeks of age $(\mathrm{P}<0.05)$, and feed conversion ratio in first week of age $(\mathrm{P}<0.05)$. Restriction duration had significant effect on feed intake in third week of age $(\mathrm{P}<0.05)$, and feed conversion ratio in third and sixth weeks of age $(\mathrm{P}<0.05)$. Coenzyme $\mathrm{Q}$ level had significant effect on feed intake in first and sixth weeks of age $(\mathrm{P}<0.05)$, body weight gain in second, fifth and sixth weeks of age $(\mathrm{P}<0.05)$, and feed conversion ratio in second and sixth weeks of age $(\mathrm{P}<0.05)$. In conclusion, considering the positive effects of feed restriction and
\end{abstract}


coenzyme Q10 on broiler yield, the simaltaneous use of feed restriction strategy and dietary coenzyme Q10 can be considered as a management program in order to improvement of broiler productivity

Keywords: feed intake, growth, feed conversion ratio, HDL, kidney

\section{INTRODUCTION}

Coenzyme Q (2,3-dimethoxy-5-methyl-6poly prenyl-1,4-benzoquinol, ubiquinone) is found in all cell membranes, especially in the membranes of the heart, liver, kidneys and pancreas (Trumpower, 2012). Coenzyme Q10 is composed of a quinidine ring and a hydrophobic chain including 10 units of isoprenoid which is known as a fat-soluble vitamin in the internal membrane of cells, and also an essential ingredient in conversion of cellular energy and production of ATP (adenosine triphosphate) in whole body cells. The quinone ring in co-enzyme Q10 in the mitochondrial respiratory chain is responsible for receiving and transferring electrons to oxygen, and the proton concentration gradient caused by the synthesis of ATP. Also, coenzyme Q10 acts as a free radicalscavenger and prevents oxidative damage in the body.Coenzyme Q10 is essential for ATP production and also acts as an antioxidant that is beneficial for reducing the effects of heat stress. In tropical areas, the restriction of providing an ideal environment for poultry farming is higher in ambient temperatures than in the areas with neutral heat for most of the year. Therefore, broiler chicks raised in these geographic areas are exposed to heat stress. Nutritionists try to increase nutrient concentrations in the diet to achieve higher growth performance (Trumpower, 2012).

Mitochondria plays the main antioxidant role where electrons leak and produce some free radicals, while if these free radicals are not scavenged by co-enzyme Q10, can oxidize intracellular macromolecules such as proteins, lipids and even DNA (Krizman et al., 2009). Since Q10 is the only fat-soluble antioxidant that is synthesized internally, one of the most important antioxidant effects of coenzyme Q10 is probably the prevention of LDL oxidation. Ubiquinol can effectively prevent peroxidation of membrane lipids, as well as lipoproteins of the bloodstream, and its practical effect is to reduce bloodmalondialdehyde levels (Geng et al., 2007). Lipoproteins are particles that transfer lipids from the intestine in the form of chylomicron and from the liver in the form of the very low density lipoprotein to the majority of tissues (for oxidation) and adipose tissue (for storage) (Takasu et al., 2012). Plasma lipoproteins include chylomicrons, very low density lipoprotein (VLDL), medium density lipoprotein (HDL), and High Density Lipoprotein (HDL), (Sheikholeslami-Vatani et al., 2011; Ooi et al., 2012 ; Blackett et al, 2013).

Many tissues are dependent on plasma triglycerides as an important source of fatty acids for oxidation or energy storage. Plasma triglycerides are transmitted through the nutrition or synthesis in the liver in the blood stream (Yasuda, 2010), in the form of chylomicron packages rich of lipoproteins and LDL packages that carry the triglyceride (Yasuda, 2010). Studies have shown that high levels of cholesterol in the blood lead to atherosclerosis and the development of arterial disease and often lead to heart attack. Low-density lipoprotein is the most important lipoprotein that carries cholesterol in the bloodstream, which causes the delivery of cholesterol from the liver to the surrounding tissues.

There are many reports on effects of feed restrictions on broiler productivity (Jahanpour, et al., 2014a; Shabani et al., 2015; Rahimi et al., 2015), immunity (Shabani et al., 2015; Rahimi et al., 2015), blood constitutes (Jahanpour et al., 2013; Shabani et al., 2015; Rahimi et al., 2015), intestine microbiota (Jahanpour et al., 2014b; Shabani et al., 2015), carcass characteristics (Jahanpour et al., 2015; Shabani et al., 2015; Rahimi et al., 2015) and organ weights (Rahimi et al., 2015). However there is not any report on simaltaneous use of coenzyme Q10 and feeding restriction programs. This study was conducted due to lack of simaltaneous researches on coenzyme Q10 and restriction feeding.

\section{MATERIALS AND METHODS}

\section{Housing and Management}

This experiment was conducted at the Islamic Azad University, Rasht Branch. The nutritional requirements of broiler chicks were met based on the recommendations of the Ross strain catalogue (Table 1).

The experiment was carried out using 60 pens in the size of $1.5 \times 1 \mathrm{~m}$. Management conditions 
Table 1. Used Diets and Nutrients Analysis during Experimental Periods

\begin{tabular}{lccc}
\hline \multicolumn{1}{c}{ Ingredient (g/kg) } & Starter & Grower & Finisher \\
\hline Corn & 53.75 & 58.88 & 61.55 \\
Soybean & 39.5 & 33.5 & 30.00 \\
Soybean Oil & 1.7 & 2.5 & 3.5 \\
Ca\%22P\%18 & 1.9 & 1.7 & 1.6 \\
CaCO3 & 1.2 & 1.6 & 1.6 \\
DL-Methionine & 0.25 & 0.22 & 0.2 \\
Lysine-Hydro-Chloride & 0.05 & 0.05 & 0.05 \\
Threonine & 0.1 & 0.1 & 0.1 \\
NaCl & 0.2 & 0.2 & 0.2 \\
Sodium bicarbonate (NaHCO3) & 0.15 & 0.15 & 0.15 \\
Vitamin- Mineral premix* & 0.5 & 0.5 & 0.5 \\
Vitamin A & 0.1 & 0.1 & 0.1 \\
Vitamin D & 0.15 & 0.1 & 0.1 \\
Vitamin E & 0.2 & 0.1 & 0.1 \\
Vitamin K & 0.1 & 0.15 & 0.1 \\
Vitamin B & 0.1 & 0.1 & 0.1 \\
Coccidioacetate & 0.05 & 0.05 & 0.05 \\
\hline \multicolumn{1}{c}{ Nutrients } & Nutrients Analysis & & \\
& Starter & Grower & Finisher \\
\hline Metabolizable Energy (ME) (kcal/kg) & 3010 & 3150 & 3200 \\
Crude Protein (\%) & 22.0 & 20.0 & 18.0 \\
Lysine (SID) (\%) & 1.44 & 1.10 & 0.95 \\
Methionine (SID) (\%) & 0.51 & 0.44 & 0.36 \\
Met+Cys (SID) (\%) & 1.09 & 0.94 & 0.36 \\
Threonine (SID) (\%) & 0.93 & 0.79 & 0.64 \\
Tryptophan (SID) (\%) & 0.25 & 0.21 & 0.18 \\
Arginine (SID) (\%) & 1.48 & 1.26 & 1.02 \\
Iso-Leucine (SID) (\%) & 0.95 & 0.81 & 0.65 \\
Calcium (\%) & 1.00 & 0.90 & 0.85 \\
Available Phosphorus (\%) & 0.50 & 0.45 & 0.42 \\
Sodium (\%) & 0.16 & 0.16 & 0.16 \\
Potassium (\%) & 0.90 & 0.90 & 0.90 \\
Chloride (\%) & 0.22 & 0.22 & 0.22 \\
\hline & & & \\
& & & \\
\hline
\end{tabular}

such as temperature, humidity, light, ventilation, nutrition and vaccination were managed in accordance with the Ross strain rearing catalogue.

\section{Birds}

A total of 600 Ross broiler chicks were purchased from the commercial local company. Chickens were weighed on the first day $(44.5 \pm$ $0.9 \mathrm{~g}$ ) and randomly distributed in pens. Fifteen treatments were repeated each in 4 replicates and so there are 60 pens in total. Each replication consisted of 10 male chicks.

\section{Treatments}

This research was organised based on a factorial experiment $(2 \times 2 \times 3)$ with 2 levels of restriction intensity $(10 \%$ and $20 \%$ lower than the standard Ross 308 guidelines), 2 durations of restriction periods ( 7 and 14 days) and 3 levels of coenzyme Q10 (0, 20 and $40 \mathrm{mg} / \mathrm{kg}$ ) (Table 2). In addition to these 12 treatments, 3 treatments were applied without quantitative feed restriction including levels of 0,20 and $40 \mathrm{mg} / \mathrm{kg}$ of coenzyme Q10 (Table 2) as controls. So, the studied treatments were as: 
Table 2. Arrangment of Studied Treatments

\begin{tabular}{cccc}
\hline Treatment & $\begin{array}{c}\text { Restriction Duration } \\
(\text { day })\end{array}$ & $\begin{array}{c}\text { Restriction Intensity } \\
(\%)\end{array}$ & $\begin{array}{c}\text { Coenzyme Q Levels } \\
(\mathrm{mg} / \mathrm{kg})\end{array}$ \\
\hline 1 & 0 & 0 & 0 \\
2 & 0 & 0 & 20 \\
3 & 0 & 0 & 40 \\
4 & 7 & 10 & 0 \\
5 & 7 & 10 & 20 \\
6 & 7 & 10 & 40 \\
7 & 14 & 10 & 0 \\
8 & 14 & 10 & 20 \\
9 & 14 & 10 & 40 \\
10 & 7 & 20 & 0 \\
11 & 7 & 20 & 20 \\
12 & 7 & 20 & 40 \\
13 & 14 & 20 & 0 \\
14 & 14 & 20 & 20 \\
15 & 14 & 20 & 40 \\
\hline
\end{tabular}

Treatment 1 : Restriction intensity (0\%), Restriction duration (0 day), Coenzyme Q10 (0 mg/kg)

Treatment 2 : Restriction intensity (0\%), Restriction duration (0 day), Coenzyme Q10 (20 mg/kg)

Treatment 3 : Restriction intensity (0\%), Restriction duration (0 day), Coenzyme Q10 (40 mg/kg)

Treatment 4 : Restriction intensity (10\%), Restriction duration (7 days), Coenzyme Q10 (0 mg/kg)

Treatment 5 : Restriction intensity (10\%), Restriction duration (7 days), Coenzyme Q10 (20)

Treatment 6 : Restriction intensity (10\%), Restriction duration (7 days), Coenzyme Q10 (40 mg/kg)

Treatment 7 : Restriction intensity (10\%), Restriction duration (14 days), Coenzyme Q10 (0 mg/kg

Treatment 8 : Restriction intensity (10\%), Restriction duration (14 days), Coenzyme Q10 (20 mg/kg)

Treatment 9 : Restriction intensity (10\%), Restriction duration (14 days), Coenzyme Q10 (40 mg/kg)
Treatment 10 : Restriction intensity (20\%), Restriction duration (7 days), Coenzyme Q10 (0 mg/kg)

Treatment 11 Restriction intensity (20\%), Restriction duration (7 days), Coenzyme Q10 (20 mg/kg)

Treatment 12 Restriction intensity (20\%), Restriction duration (7 days), Coenzyme Q10 (40 mg/kg)

Treatment 13 Restriction intensity (20\%), Restriction duration (14 days), Coenzyme Q10 (0 mg/kg)

Treatment 14 Restriction intensity (20\%), Restriction duration (14 days), Coenzyme Q10 (20 mg/kg)

Treatment 15 Restriction intensity (20\%), Restriction duration (14 days), Coenzyme Q10 (40 mg/kg)

All experimental treatments were fed as $a d$ libitum before and after the restriction period until slaughter (day 42), as in the control group. The time of quantitative feed restriction was from the age of 7th-14th days of age or 7th-21st days of age. Coenzyme Q10 was also used from 1 to 42 days of age.

\section{Coenzyme Q10}

Coenzyme Q10 (WEBBER NATURALS, Canada, Ottawa) was used in powder form. 
Coenzyme Q10 purchased as capsule form, which was removed from the capsule and added as powder to the diet.

\section{Measurments}

Feed intake and body weight gain recorded weekly. Blood samples were collected from chicks at all times so that one chick was randomly selected from each replication of each treatment and then 1 cc blood sample was taken using a $2 \mathrm{cc}$ syringe from the chick vein. After blood sampling, the syringes were placed in the thirty degrees to separate the serum from the blood. The samples were then transferred to the laboratory for analysis.

At 42 days of age, after 4 hours of starvation, from each replication one chick with a minimum difference in mean ratio of the group and for separation of carcass yield and its components, and also to evaluate the changes of the organs after slaughter and plucked followed by carcasses separation.

\section{Statistical Analysis}

The data were analyzed once in a factorial experiment with a total of 12 treatments (4th to 15th treatments) and once in a completely randomized design with a total of 15 treatments. Duncan test with $5 \%$ probability was used to compare the treatments. Data were analyzed using SPSS software.

\section{RESULTS}

\section{Performance}

The effects of restriction intensity, restriction duration and coenzyme Q level on the feed intake, body weight gain and feed converstion ratio at the first to sixth weeks are shown in Tables 3 and 4. Restriction intensity had significant effect on feed intake in first, second and sixth weeks of age $(\mathrm{P}<0.05)$, while had not had significant effect on feed intake in third, fourth and fifth weeks of age $(\mathrm{P} \geq 0.05)$. Restriction intensity had significant effect on body weight gain in second and sixth weeks of age $(\mathrm{P}<0.05)$, while had not had significant effect on body weight gain in first, third, fourth and fifth weeks of age $(P \geq 0.05)$. Restriction intensity had significant effect on feed conversion ratio in first week of age $(\mathrm{P}<0.05)$, while had not had significant effect on feed intake in second, third, fourth, fifth and sixth weeks of age $(\mathrm{P} \geq 0.05)$.

Restriction duration had significant effect on feed intake in third week of age $(\mathrm{P}<0.05)$, while had not had significant effect on feed intake in first, second, fourth, fifth and sixth weeks of age $(\mathrm{P} \geq 0.05)$. Restriction duration had not had significant effect on body weight gain in all weeks of age $(\mathrm{P} \geq 0.05)$. Restriction duration had significant effect on feed conversion ratio in third and sixth weeks of age $(\mathrm{P}<0.05)$, while had not had significant effect on feed intake in first, second, fourth and fifth weeks of age $(\mathrm{P} \geq 0.05)$.

Coenzyme Q level had significant effect on feed intake in first and sixth weeks of age $(\mathrm{P}<0.05)$, while had not had significant effect on feed intake in second, third, fourth and fifth weeks of age $(\mathrm{P} \geq 0.05)$. Coenzyme $\mathrm{Q}$ level had significant effect on body weight gain in second, fifth and sixth weeks of age $(\mathrm{P}<0.05)$, while had not had significant effect on body weight gain in first, third and fourth weeks of age $(\mathrm{P} \geq 0.05)$. Coenzyme $Q$ level had significant effect on feed conversion ratio in second and sixth weeks of age $(\mathrm{P}<0.05)$, while had not had significant effect on feed conversion ratio in first, third, fourth and fifth weeks of age $(P \geq 0.05)$.

Among 15 studied treatments, tratment 2 had the highest feed intake in first (24.725 $\mathrm{g} /$ chick/day), second (51.036 g/chick/day), third $(98.986 \mathrm{~g} /$ chick/day) and fourth $(149.800$ $\mathrm{g} /$ chick/day) weeks significantly $(\mathrm{P}<0.05)$, while tratment 3 had the highest feed intake in fifth $(199.446 \mathrm{~g} / \mathrm{chick} /$ day $)$ week $(\mathrm{P}<0.05)$, and tratment 1 had the highest feed intake in sixth (238.278 g/chick/day) week $(\mathrm{P}<0.05)$.

Among 15 studied treatments, tratment 14 had the highest body weight gain in first (22.043 $\mathrm{g} /$ chick/day) week significantly $(\mathrm{P}<0.05)$, while tratment 2 had the highest body weight gain in second $(29.982 \mathrm{~g} /$ chick/day) week $(\mathrm{P}<0.05)$, and tratment 3 had the highest body weight gain in sixth $(104.503 \mathrm{~g} /$ chick/day $)$ week $(\mathrm{P}<0.05)$. The studied treatments had not significant difference in other weeks of age $(\mathrm{P} \geq 0.05)$.

Among 15 studied treatments, tratment 10 had the best feed conversion ratio in first $(0.789$ $\mathrm{g} / \mathrm{g})$ week significantly $(\mathrm{P}<0.05)$, while tratment 8 had the best feed conversion ratio in second $(1.621 \mathrm{~g} / \mathrm{g})$ week $(\mathrm{P}<0.05)$, and also tratment 13 had the lowest feed conversion ratio in third $(1.281 \mathrm{~g} / \mathrm{g})$ week $(\mathrm{P}<0.05)$, and finally tratment 4 had the lowest feed conversion ratio in sisth $(2.073 \mathrm{~g} / \mathrm{g})$ week $(\mathrm{P}<0.05)$. The studied treatments had not significant difference in other weeks of age $(\mathrm{P} \geq 0.05)$. 


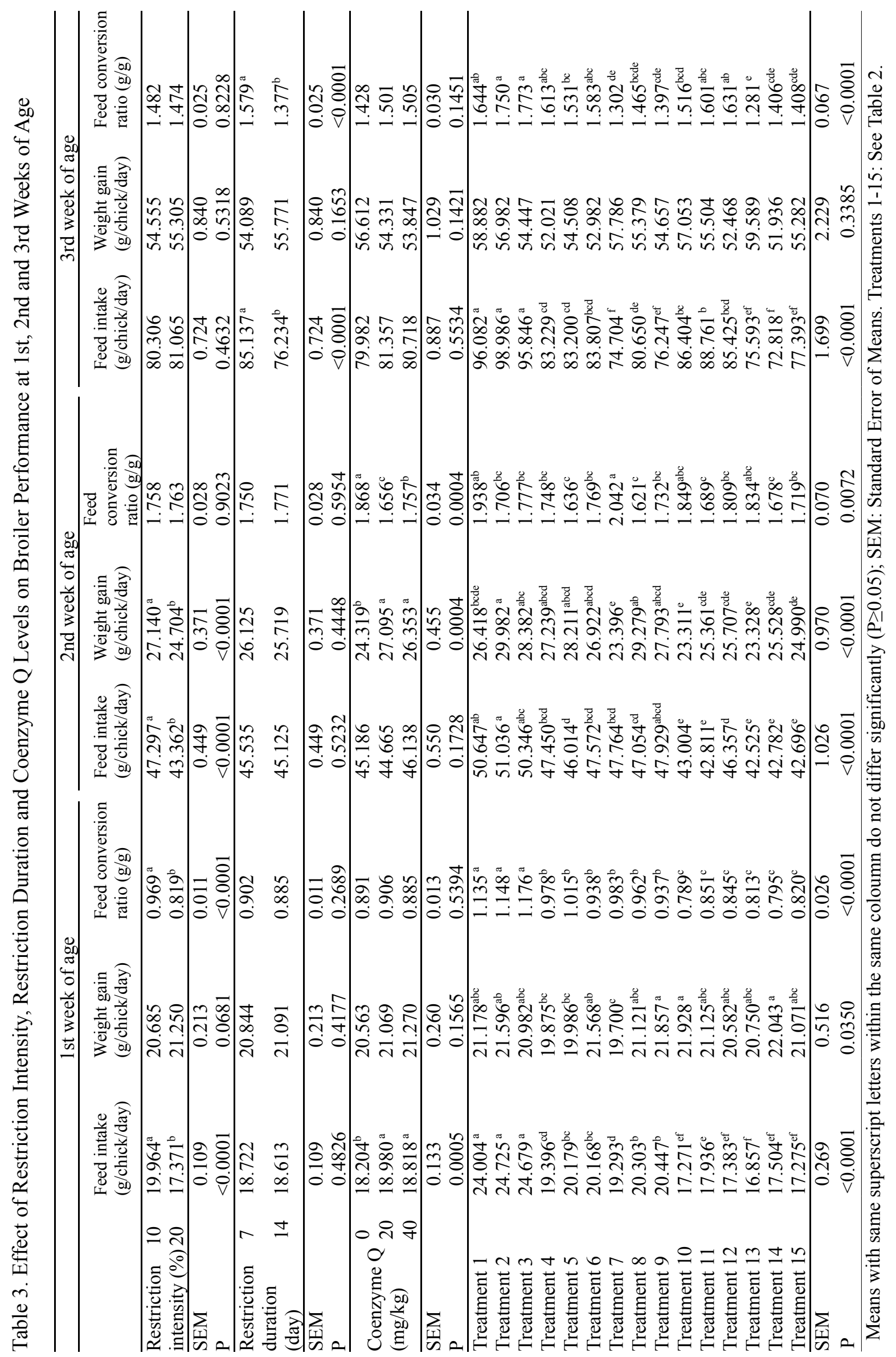




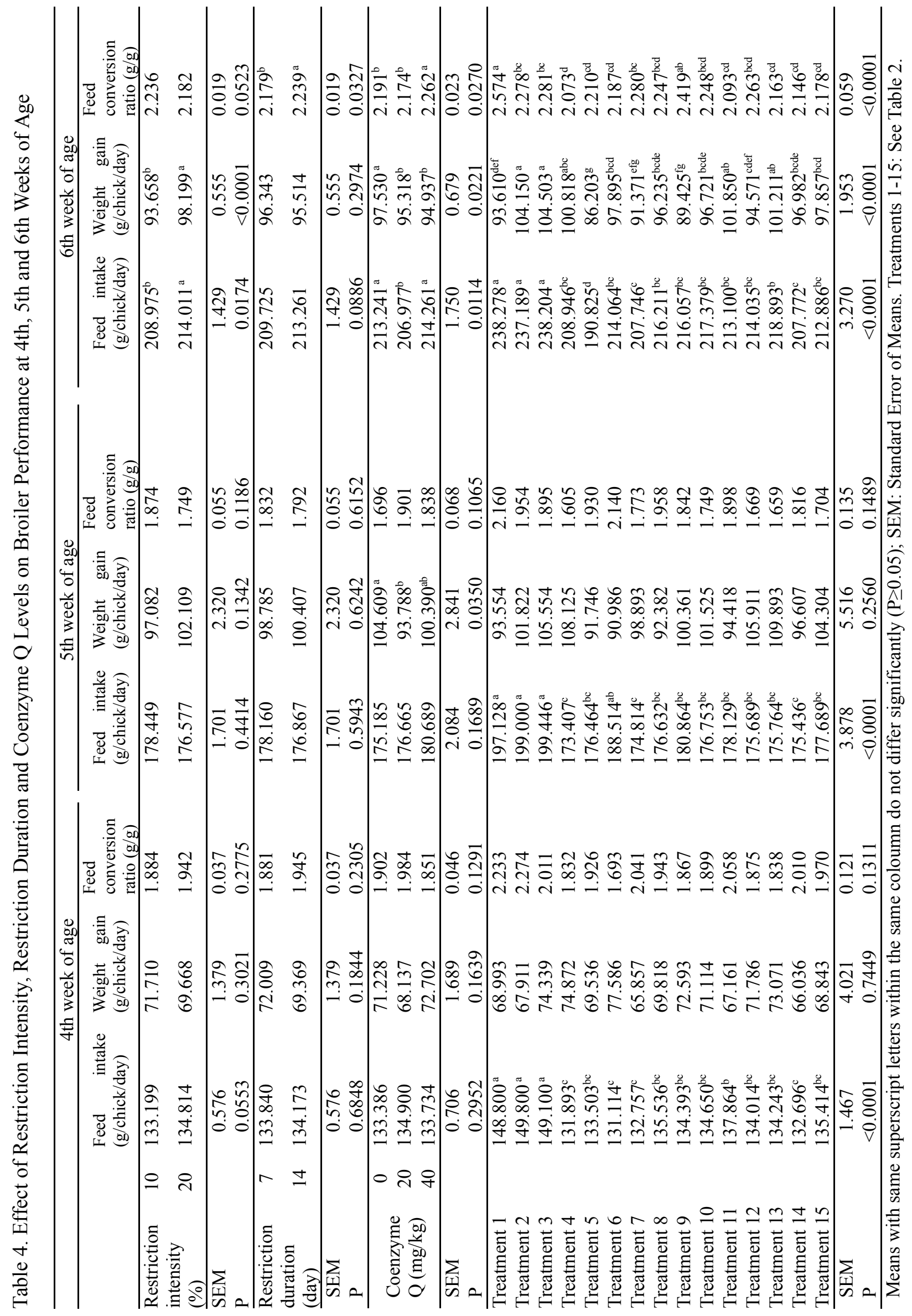




\section{Blood Plasma Constitutes}

The effects of restriction intensity, restriction duration and coenzyme $\mathrm{Q}$ level on the plasma constitutes at the 42 nd day of age are shown in Table 5.

Restriction intensity, restriction duration and coenzyme Q level had not had significant effect on plasma HDL, LDL, LDL/HDL and VLDL levels $(\mathrm{P} \geq 0.05)$. The studied treatments had not significant difference for HDL, LDL, LDL/HDL $(\mathrm{P} \geq 0.05)$. However, among 15 studied treatments, tratment 11 had the highest VLDL $(31.250 \mathrm{mg} / \mathrm{dl})$ significantly $(\mathrm{P}<0.05)$.

\section{Organ Weights}

The effects of restriction intensity, restriction duration and coenzyme Q level on the organ components at the 42 nd day of age are shown in Table 6.

Restriction intensity, restriction duration and coenzyme Q level had not had significant effect on weight and relative weight of head, lungs, kidneys, brain and testes $(\mathrm{P} \geq 0.05)$. The studied treatments had not significant difference for weight and relative weight of head, lungs, kidneys, brain and testes $(\mathrm{P} \geq 0.05)$, except among 15 studied treatments, tratment 5 had the highest relative weight of head $(3.442 \%)$ and tratment 7 also had the highest relative weight of kidneys $(0.744 \%)$ significantly $(\mathrm{P}<0.05)$.

\section{DISCUSSION}

Application of feed restriction had significant effect on the feed intake of broiler chickens, so that $40 \mathrm{mg}$ coenzymes had the highest feed intake, indicating the effect of feed restriction on feed intake. The highest feed intake was observed in theunlimited group and the lowest was observed in groups with a $20 \%$ restriction and a $20 \mathrm{mg} / \mathrm{kg}$ coenzyme Q10. In this regard, other researchers who observed reduced feed intake by restricting feed intake, reducedvolume of the gastrointestinal tract (Rameshi et al., 2007) and reduced the need for bird maintenance (Rahimi et al., 2015) due to low feed intake by them.Feed intake in coenzyme treatment was lower than treatment 1 (control) without this supplement. Since coenzyme Q10 plays a vital role in supplying energy to tissues, it can provide part of the energy needed and save energy consumption for the production of energy from the bird's body.

Appetite should be regulatedin accordance with the needs of the bird. However, broiler chicks, unlike commercial egg hatchers, are not able to adjust their consumption to maintain a constant amount of energy and adapt it to their energy requirements (Shabani et al., 2015). Additionally, selection of increase in the body weight is associated with an increase in appetite and ultimately an increase in body fat due to the positive association between growth rate and body fat preservation. Genetic factors such as strain and sex and environmental factors such as nutrition, temperature, renewal programs, and herd density affect carcass fat.Nutrition is the most important factor among the environmental factors. In nowadays strains, in addition to preservation of excessive energy than required, in addition to the growth, or the energy-to-protein ratio, increases the amount of fat in the carcass, even feeding with conventional diets based on standard tables also causes production of almost twice as much fat. Although with increasing energy levels, the conversion rate and energy efficiency improve, but these diets are expensive and less profitable in addition to increasing fat preservation (Lee and Lesson, 2001). In fact, the daily requirements of modern broiler chicks for amino acids and energy have increased with increasing growth rate, but this increase in the need for energy and amino acids is not the same and the ratio of growth to amino acids is higher than this ratio than energy (Rahimi et al., 2015). By increasing the rate of body fat in present strains, the rate of required oxygen for metabolism has also increased and they become susceptible to lack of oxygen and ultimately to metabolic diseases (Jahanpour et al., 2014).

In the case of conversion factors and the effect of feed restriction and coenzyme Q10 levels on it, there was a significant difference in the conversion coefficient between treatments with a restriction level and a supplementation level of coenzyme Q10. It seems that reducing feed intake and improvement of the conversion factor after applying feed restriction is due to a temporary decrease in the base metabolic rate in feed-limited birds (Rahimi et al., 2015) and lower body weight at early growth, which reduces the need for energy for bird storage.

The results of carcass analysis showed that there was no significant difference between head weights, head weight percentage, lung weight, lung weight percentage, kidney weight, kidney weight percentage, brain weight, brain weight percentage, testis weight, and testis weight 


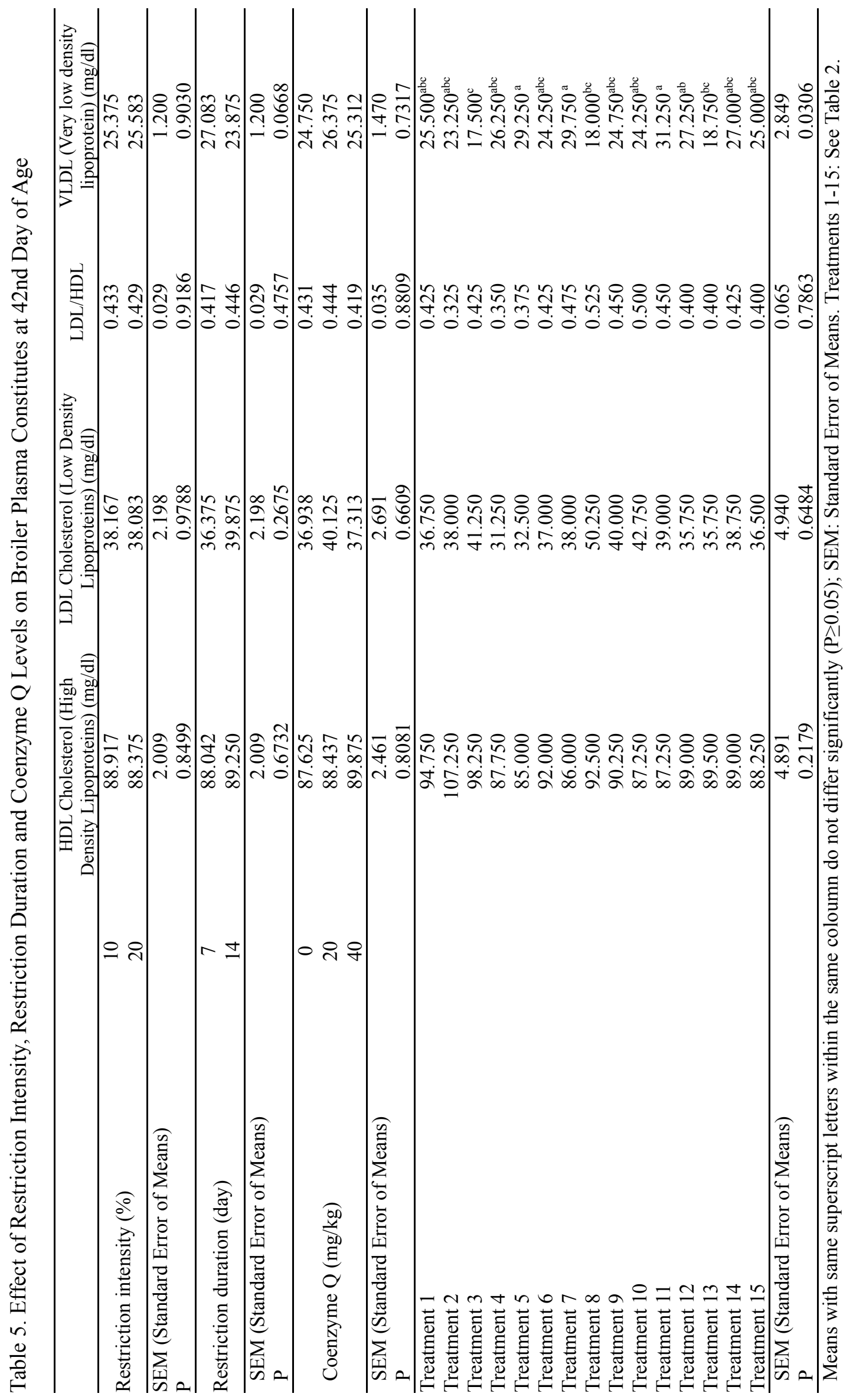




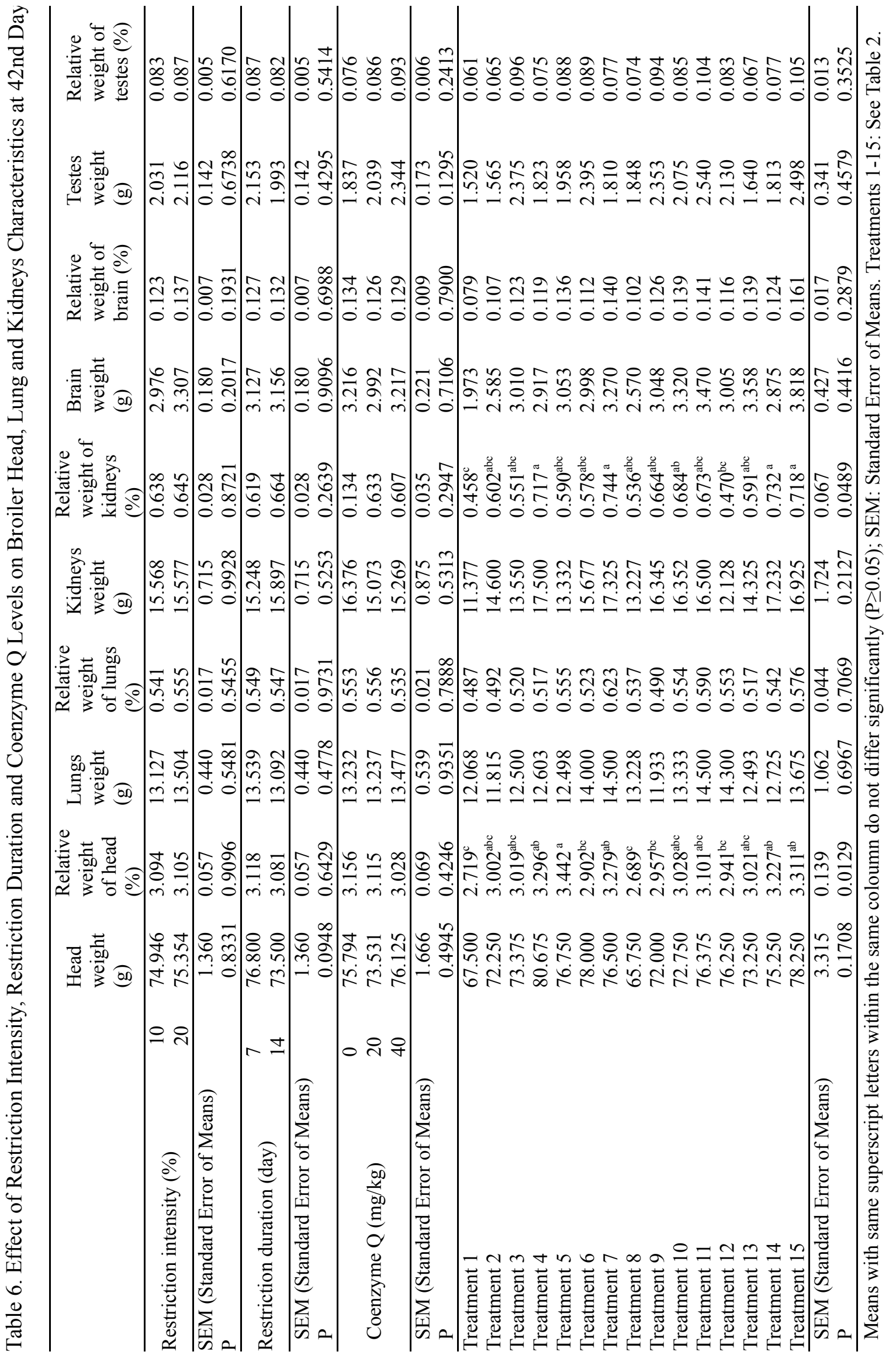


percentage $(\mathrm{P}>0.05)$. This may be due to the effective use of feed in chickens under restrictions after removal ofrestrictions on rehabilitation. However, the percentage of carcasses in the head, lungs, kidneys, brain, and testicles in the groups that received coenzyme supplementation was higher than in unrestricted treatments.

The feed restriction program up to 28 days did not have a negative effect on body weight gain, indicating that birds are receiving nutritionally adequate nutrition for growth (Onbaş1lar, et al, 2009; Wijtten et al, 2010).

The results of the study show that the application of the eight-hour feed restriction program at younger ages has no significant difference in feed intakes. In some reports, the effect of different feed restrictions on broiler chickens performance was investigated. There was no significant difference in feed intake (Butzen et al., 2013; Saber et al., 2011). The strain factor is one of the factors affecting feed intake (Wijtten et al., 2010). Possible reason for having no feed intake can be that the bird's digestive tract can adapt to nutritional restrictions. Research results showed that in the long-term restriction of feed along with age, as a response the digestive systemwillincreaseits storage parts such as strain, pre-gastric and ginger in order to adapt the feed restriction aimed touse and maintain most feed so that the bird can fed more of the feed at the hours (Ozkan et al., 2010).

A review by Fanooci and Torki (2010) showed that there is no significant difference in the total feed conversion factor (49-9 days) between finite feeding chickens and non-limited control diets.

Wijtten et al. (2010) stated that the type of feed restriction and bird genetics is effective on the results of breast and abdominal fat percentage. Body fat, especially abdominal fat, is affected by many factors such as strain, diet, sex, temperature and rearing conditions. There are various reports on the effects of different feed restriction programs on the level of abdominal fat. This difference may be due to genetic variations, intensity and duration of feed restriction, rearing period, and feed intake (Dastar et al., 2013). Richards et al., (2003), Liew et al., (2003), and Mellouk et al., (2018) reported different results on another commercial strain i.e. Cobb 500. Recent reports (Jahanpour at al., 2015) observed that feed restriction programs have no effect on carcass fat content.

\section{CONCLUSION}

As conclusion, considering the positive effects of feed restriction and coenzyme Q10 on broiler yield, the simaltaneous use of feed restriction strategy and dietary coenzyme Q10 can be considered as a management program in order to improvement of broiler productivity. Coenzyme Q10 (20 mg/kg) reduced plasma VLDL level and increased yield, so the use of coenzyme Q10 can be effective for improvement of boiler performance.

\section{ACKNOWLEDGEMENTS}

This manuscript is prepared based on $\mathrm{PhD}$ thesis of first author at Science and Research Branch, Islamic Azad University, Tehran, Iran. We are grateful to the Science and Research Branch, Islamic Azad University, Tehran, Iran for support.

\section{REFERENCES}

Blackett, P., J.Tryggestad and S. Krishnan. 2013. Lipoprotein abnormalities in compound heterozygous lipoprotein lipase deficiency after treatment with a low-fat diet and orlistat. J. Clin. Lipid. 7(2):132-9.

Butzen, F., A. Ribeiro and M. Vieira. 2013. Early feed restriction in broilers. IPerformance, body fraction weights, and meat quality. J. Applied Poult. Res. 22:251259.

Dastar, B., M. Shams sharg and S. Zerehdaran. 2013. Evaluate function and incidence of of ascites in broiler chickens in response to feed restriction and nutritional programs. J. Anim. Sci. Iran Res. 5:268-274.

Fanooci, M and M. Torki. 2010. Effects of qualitative dietary restriction on performance, carcass characteristics, white blood cell count and humoral immune response of broiler chicks. Global Vet. 4: 277-282

Geng, A., B. Li and Y. Guo. 2007. Effects of dietary L-carnitine and coenzyme Q10 at different supplemental ages on growth performance and some immune response in ascites-susceptible broilers. Arch. Anim. Nutr. 61:50-60.

Jahanpour, H., Seidavi, A. R. and Qotbi, A. A. A. 2014a. Effects of intensity and duration of quantitative restriction of feed on broiler performance. J. Hellenic Vet. Med. Soc. 
65(2):83-98

Jahanpour, H., Seidavi, A. R., Qotbi, A. A. A. and R. Payan-Carreira. 2013. Effects of Two Levels of Quantitative Feed Restriction for a 7- or 14- Days Period on Broilers Blood Parameters. Acta Sci. Vet. 41:1144, 1-11.

Jahanpour, H., Seidavi, A. R., Qotbi, A. A. A., Delgado, F. and S. Gamboa. 2014b. Effect of intensity and duration of quantitative feed restriction on broiler caecum microbiota. Indian J. Anim. Sci. 84(5):554-558.

Jahanpour, H., $\quad$ Seidavi, A., $\quad$ Qotbi, A. A. A., Van Den Hoven, R., Rocha e Silva, S., Laudadio, V. and V. Tufarelli. 2015. Effects of the level and duration of feeding restriction on carcass components of broilers. Arch. Anim. Breed. 58:99-105.

Khetani, T.L., T.T.Nkukwana and M. Mhimonyo. 2009. Effect of quantitative feed restriction on broiler performance. Trop. Anim. Health. Prod. 41:379-384.

Krizman, P.J., M. Prosek, and A. Smidovnik. 2012. Poultry products with increased content of CoQ10 prepared from chickens fed with supplemental CoQ10. Ch.9 th. In: Eissa AHA (ed) Trends in Vital Feed and control engineering. InTech, Rijeka, Croatia, pp 165-186.

Lee, K.H and S. Leeson. 2001. Performance of broilers fed limited quantities of feed or nutrients during seven to fourteen days of age. Poult. Sci. 80:446-456.

Liew, P. K., Zulkifli, I., Hair-Bejo, M., Omar, A. R., and D.A. Israf. 2003. Effects of early age feed restriction and heat conditioning on heat shock protein 70 expression, resistance to infectious bursal disease, and growth in male broiler chickens subjected to heat stress. Poult. Sci. 82(12):1879-1885.

Mellouk, N., Ramé, C., Marchand, M., Staub, C., Touzé, J.L., Venturi, É., Mercerand, F., Travel, A., Chartrin, P., Lecompte, F. and L. Ma. 2018. Effect of different levels of feed restriction and fish oil fatty acid supplementation on fat deposition by using different techniques, plasma levels and mRNA expression of several adipokines in broiler breeder hens. Plos One. 13(1):e0191121.

Onbaşılar, E., S. Yalçın, E. Torlak and P. Özdemir. 2009. Effects of early feed restriction on live performance, carcass characteristics, meat and liver composition, some blood parameters, heterophil lymphocyte ratio, antibody production and tonic immobility duration. Trop. Anim. Health Prod. 41:1513-1519.

Ooi, E., M. Betsy and S. Russell. 2012. Diffenderfer Apolipoprotein B-100containing lipoprotein metabolism in subjects with lipoprotein lipase gene mutations. Arterioscler Thromb Vasc Biol. 32(2):459-66.

Özkan, S., C. Takma and A. Yahav. 2010. The effects of feed restriction and ambient temperature on growth and ascitesmortality of broilers reared at high altitudel. Poult. Sci. 89:974-985.

Rahimi, S., Seidavi, A.R., Sahraei., Blanco, F.P., Schiavone, A. and Martínez Marín, A.L. 2015. Effects of feed restriction and diet nutrient density during re-alimentation on growth performance, carcass traits, organ weight, blood parameters and the immune response of broilers. Italian J. Anim. Sci. 14(3):583-590.

Richards, M.P., Poch, S.M., Coon, C.N., Rosebrough, R.W., Ashwell, C.M., and J.P. McMurtry. 2003. Feed restriction significantly alters lipogenic gene expression in broiler breeder chickens. J. Nutr. 133(3), 707-715.

Saber, N., N. Maheri-Sis and A. Shaddel-Telli. 2011. Effect of feed restriction on growth performance of broiler chickens. Ann. Biol. Res. 2:247-252.

Shabani, S., Seidavi, A. R., Asadpour, L. and M. Corazzin. 2015. Effects of physical form of diet and intensity and duration of feed restriction on the growth performance, blood variables, microbial flora, immunity, and carcass and organ characteristics of broiler chickens. Livestock Sci. 180:150157.

Sheikholeslami-Vatani, D., S. Ahmadi and H. Mojtahedi. 2011. Effect of moderate and high intensity resistant exercises on cardiovascular risk factors in non- athlete university students. Kowsar Med J. 16(2):115-21.

Takasu, S., M. Mutoh and M. Takahashi. 2011. Lipoprotein lipase as a candidate target for cancer prevention/ therapy. Biochem. Res. Int. 2012:1-8.

Trumpower, B. ed., 2012. Function of quinones in energy conserving systems. Elsevier. Amestardam.

Wijtten, P., E. Hangoor and J. Sparla. 2010. 
Dietaryamino acid levels and feed restriction affect small intestinal development, mortality, and weight gain of male broilers. Poult. Sci. 89:1424-1439.

Yasuda, T., T. Ishida and D.J. Rader. 2010. Update on the role of endothelial lipase in highdensity lipoprotein metabolism, reverse cholesterol transport, and atherosclerosis.
Jpn. Circ. J. 74(11):2263-70.

Yousefi, K. 2013. The effect of amino acids levels and methods of feeding on performance, development of ascites, immune response and intestinal structure of Arian broilers. Ph.D Disertation in Poultry Nutrition, College of Agriculture and Natural Resources Karaj, Iran. 